lacrosse team. *urtis Keaton, a kinesiology major from Metairie, La., will be inducted into the JMU Athletics Hall of Fame. He was a running back on the JMU football team and was drafted by the NFL's Cincinnati Bengals in 2000. He played two seasons for the Bengals and the 2002 season for the New Orleans Saints. * Akshan, aka Nickia Palmer, released his new EP Island Rocker this summer. He is the lead singer for the Dub City
Renegades and his 2010 single release, Jealous Type, garnered more than 10,000 downloads in its first week. Jamaican born Akshan's music blends vintage reggae with a pop-rock sound. Follow him on Facebook and at Akshanmusic.com. * Katrina Hunter Bigelow was promoted to regional consultant for Ambit Energy. She and her husband, Doug ('99), live in Emmitsburg, Md., with their sons, Hunter and Parker. * Agatha Kulesza published her first book, Sweaty Armpit Duct Tape Girl: A Memoir. She shares a courageously honest story of what it takes to be happy, according to Amazon. com. After graduation Kulesza worked for a Big 4 public accounting firm before branching out and creating her own accounting and bookkeeping service company. She also has created an online course for personal finance, adding an Internet component to her business.
01 Jason Long will be posthumously inducted into the JMU Athletics Hall of Fame during Homecoming Weekend. Long was a member of the track/cross country team. * R. Lee McVey II was named to the Top 40 under 40 in The Business Journal of Tri-Cities Tennessee/Virginia. The McVey Law Firm serves both Tennessee and Virginia. McVey also serves as director of baseball operations Continued on Page 61

\title{
Turning vision into action
}

\author{
Virginia Cbamber of Commerce president belps bring jobs to the commonwealtb \\ By Amelia Wood ('iz)
}

I:n numerous jobs developing Virginia's economy, Barry E. DuVal ('81) has effectively turned vision into action, helping bring tens of thousands of jobs to the commonwealth.

It's a way of leading he saw demonstrated by JMU President Emeritus Ronald E. Carrier. "Dr. Carrier had a vision. He knew where he was going and could take other people with him. I have tried to emulate his leadership style in the positions I've held," DuVal says.

With that vision, DuVal brought other aspects of his Madison Experience into his jobs, which most currently is president and CEO of the Virginia Chamber of Commerce. At JMU, he was president of the JMU Honor Council, a member of Intervarsity and a Student Government Association senator. The governor of Virginia also appointed him to the JMU Board of Visitors this year.

DuVal says he majored in psychology because he believed understanding people would be a key part of his career. DuVal minored in paralegal studies. Eileen Nelson, professor emerita of psychology, and her late husband,

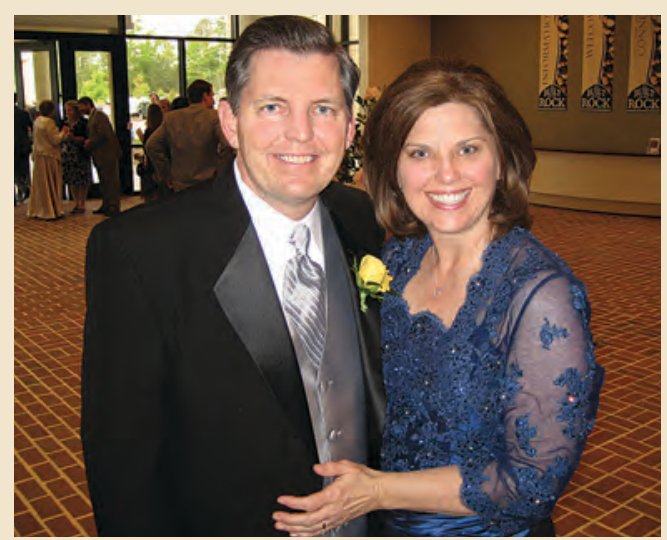

JMU Board of Visitors member Barry E. DuVal ('81) and wife, Cindy Wermers DuVal ('81), celebrate at the grand opening of the Forbes Center for the Performing Arts in February. The longtime JMU supporters funded the center's DuVal Lecture Hall.
Japan and Europe to Newport News. His actions more than compensated for the jobs the shipyard eliminated.

After six years in office, DuVal ended his work on the council.

"We had three young children, and I was balancing my professional life with my personal life and my political life. I had to make a choice," he says.

Still, he stayed involved in public life, serving as president and CEO of Hampton Roads Partnership, and later as Secretary of Commerce and Trade under Virginia's then-Gov. Jim Gilmore from 1998 to 2002. During his time under Gilmore, DuVal helped bring more than 100,000 jobs to the commonwealth with 1,000 economic development projects.

From 2002 until June 30, 2010, DuVal was president and CEO of Kaufman \& Canoles Consulting LLC. On July 1, 2010, DuVal became president and CEO of the Virginia Chamber of Commerce.

"The Virginia Chamber of Commerce provides leadership for the business community in Virginia," DuVal says. Working with the governor and the genWilliam Nelson, professor emeritus of political science and law, both inspired DuVal to pursue those areas of study.

Within two years of graduating, DuVal co-founded and served as the president and principal broker of DuVal Associates Inc. Realtors. In 1988, Newport News voters elected DuVal to city council, and by 1990 he was mayor.

The youngest mayor elected in the history of Newport News, DuVal garnered the most votes ever recorded in the city's history when he was re-elected in 1992.

As mayor, he focused on economic development. When a Newport News shipyard executive told DuVal the company was cutting its workforce from 30,000 to 18,000 , DuVal began luring other companies to the city.

National chains were moving their anchor stores to busier roads, so DuVal filled in old shopping center sites with call centers for UPS and $\mathrm{MCl}$, among others. DuVal also brought industrial firms from eral assembly, DuVal helps craft business policy for Virginia. DuVal's JMU ties permeate his family. DuVal married Cindy ('13) is a junior at JMU. Daughter Rachel DuVal Nilson is a 2006 JMU alumna. Son Daniel is a 2009 University of Virginia graduate and is married to Rebecca Webb DuVal, a 2009 JMU alumna.

Barry and Cindy visit campus often to participate in JMU events, like the grand opening gala for the Forbes Center. He also presented a James Madison Lecture for JMU's former Founders Day Convocation. The DuVals are longtime donors to JMU and most recently helped fund DuVal Lecture Hall in the Forbes Center for the Performing Arts. "It's beautiful!" Barry exclaims. "We are very proud of this facility."

* Visit Barry DuVal's Virginia Chamber of Commerce president's web page at www.vachamber.com/general.asp?id=277. Wermers DuVal ('81), and they have three children: Catherine 